\title{
TWO HUNDRED AND FIFTY YEARS AGO: THE BANKSIAN BOTANICAL 'SUITE' ARRIVES IN MADEIRA ON HMS ENDEAVOUR
}

\author{
Jordan Goodman*
}

\begin{abstract}
HMS Endeavour, the first British ship to circumnavigate the world on a scientific mission, had its first stop in Funchal on 12 August 1768 on the way to the Pacific. It was not a big ship and it sailed on its own. Not only was this a scientific voyage -initially making for Tahiti where Venus's track across the sky could be accurately measured- but it had a remarkable and unique entourage dedicated to observing and recording the natural world. Though the ship's commander, Lieutenant James Cook, had a good reason to call into the island's principal port, it could have been otherwise: sea conditions, unpredictable at the best of times, might have forced him to head for Tenerife instead. Had this happened, the botanical history of Madeira might have been quite different. Fortunately for Joseph Banks and Daniel Solander, the ship's botanists, the sea was kind and the two men, the latter Linnaeus's best student, were able to bring Hans Sloane's pioneering botanical observations, made more than seventy years earlier, into the modern age.
\end{abstract}

KeYwords: Banks, Botanical history, HMS Endeavour, Madeira, Solander.

\section{HACE 250 AÑOS: BANKS LLEGA A MADEIRA EN EL ENDEAVOUR}

\section{RESUMEN}

El Endeavour, el primer barco inglés en circunnavegar el Globo en misión científica, hizo su primera parada en Funchal el 12 de agosto de 1768, en su camino hacia el Pacífico. No era un barco grande y navegaba en solitario. Además de su principal misión -observar y medir el tránsito de Venus en Tahití-, debía observar y registrar la naturaleza de los lugares visitados. Pese a que el comandante de la nave, el teniente James Cook, tenía buenas razones para recalar en Funchal, las condiciones del mar, del todo impredecibles, le habrían podido forzar a recalar más al sur, en Tenerife. De haber ocurrido esto, la historia botánica de Madeira hubiera sido bien diferente. Afortunadamente para los dos botánicos de a bordo, Joseph Banks y Daniel Solander, este último el mejor discípulo de Linneo, el mar estaba en calma, lo que les posibilitó conocer Madeira, y de esta manera recuperar las pioneras observaciones botánicas realizadas unos setenta años antes de esta visita por Hans Sloane, para la modernidad.

Palabras Clave: Banks, Endeavour, Historia de la Botánica, Madeira, Solander. 


\section{INTRODUCTION}

My intention in this paper is to go behind the scenes of this very famous expedition, to explain how it was put together, how the ship, its commander and particularly its entourage of 'scientific gentlemen' came to sail together and to the island of Madeira, what they did here and what significance it held especially for the two botanists, Joseph Banks and Daniel Solander, and the principal artist, Sydney Parkinson.

My main argument is that were it not for two historical tipping points, the Endeavour would not have visited Madeira, history would have been different, and this paper would have had no reason to be written. But before discussing these tipping points, it is necessary to fill in the background to the reasons for the Endeavour's voyage in the first place.

There are many beginnings to the voyage but my story starts on 15 February 1768 for it was then that King George III received a 'Memorial for Improving Natural Knowledge' from London's Royal Society (Carter 1995; Cook 2004). The Society was appealing to the King for his financial support to send men and instruments to a convenient spot in the southern hemisphere somewhere in a rectangle bounded by a latitude 'not exceeding 30 degrees [south] and between the $140^{\text {th }}$ and $180^{\text {th }}$ degrees of longitude west', determined by Nevil Maskelyne, the Astronomer Royal, as the best place to observe the transit of Venus, predicted to be visible there on 3 June 1769 -the next event would not occur again until 1874 (the original memorial is in the Royal Society Archives, RS Misc. MSS V 39; Williams 1998). The Royal Society had been discussing how they would contribute to observing and measuring this rare but crucially important astronomical event, from which they hoped they could calculate the size of the solar system, since at least June 1766. On 19 November 1767, the Society's newly-constituted Committee for the Transit had agreed the general plan of sending observers to the south, and that the ship taking them to the Pacific would need to be rounding Cape Horn no later than January 1769 (Beaglehole 1955). Time was running out for adequate preparations to be made. 'The Royal Society', the memorial pleaded, 'was in no condition to defray this Expence (which they had estimated at $£ 4000-£ 400,000$ in today's money- not including the cost of the ships), their Annual Income being scarcely sufficient to carry on the necessary business of the Society'. Time was of the essence. Several other European powers (France, Spain, Denmark and Russia were singled out) were already making their own preparations for the event and Britain, in the forefront of astronomical science, simply could not afford to be a bystander. The memorial was signed by James Douglas, Earl of Morton, the Society's president, and fourteen fellows including Benjamin Franklin and Nevil Maskelyne (Beaglehole 1955; Woolf 1959; Wulf 2012).

* Department of Science and Technology Studies, University College London, London, United Kingdom. Corresponding author: goodman@ucl.ac.uk. 
By late February 1768, the King had given his consent to defray the costs of sending observers to the southern hemisphere and, at the same time, he ordered the Admiralty to provide a suitable ship to take them to their destination (Carter 1995; Beaglehole 1955; Knight 1933). By the end of March, the Admiralty had agreed which ship to purchase. It was called the Earl of Pembroke. It had been built in Whitby a little more than three years earlier and was currently lying unused in the Thames to the east of the present location of Tower Bridge. Just over a week later, on 5 April, the Admiralty informed the Navy Board, who were responsible for the day-to-day administration of the Royal Navy, that the ship, now renamed HMS Endeavour, and at the relatively small size of 32 metres long and 9 metres wide (the Titanic was almost ten times longer and a football pitch is three times longer), should be prepared and armed as necessary for 'conveying to the southward such persons as shall be thought proper for making observations on the passage of the planet Venus over the sun's disc' (Knight 1933).

For the time being, the ship had no commander and, more importantly, no specific location in the southern hemisphere for observing the astronomical event. In the discussions leading to the drafting of the memorial, however, suggestions were made that one of the Marquesas Islands, which had been sighted by Alvaro de Mendaña y Neira in 1595, or one of two islands in Tonga (then named Rotterdam and Amsterdam Islands and last seen by Abel Tasman in 1643), might be suitable, but no one was certain precisely where in the ocean these likely candidates were (Beaglehole 1955).

While the issue of the ship's destination remained unresolved, that of the Endeavour's commander was moving along swiftly. Sometime during the week after the order to get the ship ready for sea, that is before mid -April 1768, the Admiralty found in James Cook the man that they wished to appoint to command. Cook was not a young man and, as far as the Royal Navy was concerned, fairly inexperienced but he certainly had talent (Beaglehole 1962). He was born in Yorkshire and first went to sea when he was eighteen years old working for a Whitby company carrying coal from northeast England to London. Once Cook's apprenticeship was over he sailed on ships throughout the North Sea, from Holland in the south to Norway in the north. He did well, and he was promoted but then, and for no reason that has come down to us, he volunteered, in 1755, to join the Royal Navy in Wapping, east London. Two years later he became a master, qualified, therefore, to sail naval ships. By then however, war had erupted between Britain and France and their respective allies and Cook was sent on a naval squadron to North America where he participated in several battles in and around the St. Lawrence River. When in 1763 , peace came, bringing an end to what was then referred to as the Seven Years' War, Cook, who had by now distinguished himself in surveying and cartography, in addition to navigation, was appointed to be the surveyor on a naval expedition to Newfoundland over which Britain had been given sovereignty under the terms of the peace treaty. There he remained, apart from short spells back in London, until the early part of November 1767, when he returned bearing a cache of elegantly produced maps and hydrographic surveys of the coasts of this geographically complicated island. 
Cook intended to return to Newfoundland in the spring of 1768 , once he was satisfied that the engravers were competently handling his manuscript maps, but this is not what happened. His requisitions to the Admiralty to prepare his surveying ship for the next season coincided precisely with their search for someone to command HMS Endeavour. Cook never crossed the north Atlantic again. Instead, from now until his murder in Hawaii in February 1779, his life was bound up wholly with the Pacific.

It was now May 1768. The Endeavour was being prepared but where was it heading? Cook, and Charles Green, whom the Royal Society had already appointed as the expedition's astronomer, were the designated observers. They needed an island on which they could erect their observatory. Would Cook be able to find the Marquesas or Amsterdam and Rotterdam island? And if he could, would the ship be welcomed or attacked?

While these questions were being discussed in the Admiralty and the Royal Society, something wholly unexpected happened (Williams 1998). On 20 May 1768, Samuel Wallis, a naval commander, arrived in London with scarcely believable news. In August 1766, Wallis had been given command of HMS Dolphin whose objective was to sail into the Pacific in search of Terra Australis Incognita, the substantial land mass that was supposed to exist in southern latitudes -Alexander Dalrymple, the noted hydrographer and cartographer, preferred to use the term 'Southern Continent' and many followed his example (Cock 1999; Patel 2016; Williams 1996). Wallis reported that high land had been seen in the distance during the voyage but what caught his and everyone else's imagination was his discovery of an extraordinary island and civilization, to which he gave the name, in honour of his sovereign, of 'King George the Third's Island' (Salmond 2010). Wallis was an excellent navigator and equipped with the latest instruments to calculate that most elusive of navigational parameters -longitude. He reported that this island, which had abundant food and water, a healthy climate, a good anchorage and welcoming people, and which we now know as Tahiti, lay at 17 degrees 30 minutes latitude and 150 degrees longitude, west of London, precisely within Maskelyne's oceanic rectangle.

Wallis knew nothing about the Royal Society's interest in tracking Venus and the Admiralty did not expect him to arrive in London for at least a year, in other words, sometime in 1769. As it happened, because of widespread illness among his crew, his own weakness and serious doubts that his ship could stand any more wear and tear, Wallis had decided to abandon a part of his surveying objectives and hurry home by way of the Cape of Good Hope - in spite of his instructions to return by way of Cape Horn (Patel 2016).

Wallis's discovery of the island and of an excellent anchorage in the very north of the island, at a place he named Port Royal, or Matavai Bay in Tahitian, where he anchored on 23 June 1767, could not have been better news for the Royal Society. The vague destination of the Marquesas and Tonga was now replaced by a firm, precise and, therefore, perfectly findable location. The predicted date of the transit was almost the same as the date of Wallis's anchorage so that what he described then, especially the weather, would equally apply to the Endeavour's stay. On 9 June 1768, a fortnight after Cook had officially taken charge of the Endeavour, the Council 
of the Royal Society endorsed the choice of the island discovered by Wallis as the expedition's destination (Beaglehole 1955; Knight 1933). In the following month, the Admiralty reaffirmed the Society's decision of where to observe the track of Venus when they presented their instructions to James Cook, who had, in the meantime, been promoted to the rank of lieutenant (Beaglehole 1955). To guide him to Tahiti, the Admiralty presented Cook with copies of 'such Surveys, plans and Views of the Island and Harbour as were taken by Capt Wallis, and the Officers of the Dolphin when she was there' (Beaglehole 1955).

The Royal Society Council meeting minute of 9 June 1768 recorded the important concrete decisions that had been taken since the 'Memorial' of mid -February in order to effect this astronomical expedition: the observers, Cook and Green, had been chosen and their salaries agreed; the ship and its commander had been commissioned; and the location in Maskelyne's rectangle of southern sea, pinpointed.

At this point, the scientific aspects of Cook's expedition to the Pacific were astronomical and geographic. Had the expedition remained this way, then Madeira would not have played any significant role in this story. This was the first of the two tipping points. Instead of the narrow focus of the expedition, it broadened in almost no time at all and in unexpected directions.

What happened was this. The minute of the Royal Society's Council meeting which recorded Cook and Green's appointment, also had a small note to the effect that the Society's secretary would be asking the Admiralty that 'Joseph Banks... being desirous of undertaking the same voyage... for the Advancement of useful knowledge... He... together with his Suite... be received on board of the Ship, under the Command of Captain Cook' (Beaglehole 1962; Beaglehole 1955). The purpose of the expedition was about to be completely redefined and Banks was solely responsible for that.

Who was Banks and how did he find himself in this position? Banks was born on 13 February 1743 in London. His formal education began at the age of nine following a curriculum primarily in Latin, Greek and English literature, which he studied dutifully but without much enthusiasm or success. When he was seventeen years old, he enrolled at Christ Church, Oxford. During his first year at the university, Joseph's father William died. When he came of age in 1764, Banks inherited his father's extensive estates and thus became an extremely wealthy young man.

Banks continued to attend university and during his time there he became intensely interested in natural history. To get some kind of formal instruction in botany -the subject was not on the curriculum at Oxford-Banks, who now had money to spend, paid to be present at a set of lectures on botany delivered during the summer of 1764 to a group of sixty enthusiastic students by Israel Lyons, a Cambridge botanist and astronomer (Glyn 2002). Lyons was one of the earliest exponents of the new Linnaean system in Britain and shared his understanding of and passion for it with Banks.

Banks left Oxford without a degree shortly after Lyons's lectures. He could have done anything he liked -gone into the law, church, or the City- or simply enjoyed himself as a wealthy young man about town, but his great enthusiasm was 
for plants. As soon as he could he moved to Bloomsbury close by the newly-opened British Museum, with Sir Hans Sloane's collection at its core, to which he obtained a reader's ticket on 3 August 1764, and there he threw himself into the study of botany, helped by its world-famous herbaria, illustrations and texts.

At that time, the British Museum was the only public space in London where natural history could be studied. While he was there, Banks became acquainted with others like himself, and through his new contacts and friendships, he was elected a Fellow of the Royal Society on 1 May 1766, aged twenty-three.

Like every enthusiastic naturalist, Banks went out and about botanizing, observing and collecting living specimens in their habitat. A rare chance to botanize beyond Europe came Banks's way in April 1766, when an old school friend, Lieutenant Constantine Phipps, invited him to join HMS Niger bound for fisheries duty in Newfoundland and Labrador, which Banks eagerly accepted.

The Niger, with Banks aboard, was away from England for nine months, from 22 April 1766. Six of those months were spent in and around Newfoundland and Labrador. Though he and James Cook were in the same harbour on 27 and 28 October 1766, there is no evidence that they met on this occasion (Carter 1988). Coming home by way of Lisbon on 26 January 1767, Banks landed with a substantial haul of new natural specimens - plants, birds, insects and fishes- many of them new to European science and all of which needed to be classified and some of which illustrated.

Banks attended his first Royal Society meeting on 12 February 1767 shortly after his return from Newfoundland and Labrador (Carter 1988). Though he was not in London when, in November 1767, the Committee of the Transit recorded its decisions about how the Society wished to have Venus's track observed, it is very likely that he knew about it shortly thereafter and certainly by the time of the 'Memorial' to the King on 15 February 1768, Banks had made up his mind to try and join the expedition (Carter 1988). Over the next few months, by dint of careful negotiations and relationships, especially with Philip Stephens, the First Secretary of the Admiralty, whom he had met at the British Museum, Banks convinced those in authority that he should be go to the South Seas (Carter 1988). The Royal Society Council minute of 7 June 1768, requested the Admiralty to accept Banks, accompanied by seven others, including two artists, a secretary and a team of assistants and servants, all paid for by him (a critical consideration), to join the ship (Carter 1988; Cook 2004).

On 22 July the Admiralty informed Cook that the Royal Society's request had been accepted, but, instead of seven in Banks's accompanying suite, they now stipulated that eight, in addition to Banks, would be going (UK National Archives, ADM2/94, 22 July 1768). 
Not far from the Reading Room where Banks immersed himself in the British Museum's natural history riches, Daniel Solander, Linnaeus's best and favourite student, who, in 1763, had been invited to England, especially by the botanist John Ellis, to expound his teacher's new system of classification, was busily working on cataloguing the Museum's natural history collections. A year after arriving in London Solander was made a Fellow of the Royal Society (Duyker 1998).

Ten years Banks's senior, Solander took over the latter's botanical education where Lyons had left it off. Solander had prepared Banks for the Newfoundland voyage and when he returned, Solander helped him catalogue the plants that had been collected (this and the following is taken from Chambers 2007, 16 November 1784). It is not surprising, therefore, that Banks confided in Solander that he was planning to join the Endeavour -he was 'very excited by my plans, and immediately offered to furnish me with information on every part of natural history which might be encountered on such an ambitious and unparalleled mission', Banks later remarked. It was several days later when they were dining at the home of a mutual friend, that the topic of the Endeavour came up and, according to Banks, Solander jumped to his feet and asked Banks if he wanted a companion to join him. Banks replied, 'Someone like you would be a constant benefit and pleasure to me!'. Solander did not hesitate. 'I want to go with you', he exclaimed.

On 24 June 1768 Solander wrote to the Trustees of the British Museum telling them about Banks's offer. Solander added that this unique opportunity would allow him to collect for the Museum (Duyker and Tingbrand 1995, 24 June 1768 and 1 December 1768). They agreed to his leave of absence. Banks may have been well known in the Royal Society, and in the British Museum's Reading Room, but in the world of botany, it was Solander who was the more famous. He was a key addition to the voyage.

This was now quite a different expedition from what had been in the Royal Society's mind when they petitioned the King for financial help. It wasn't just advances in astronomy and geography that would hopefully flow from the expedition but now, natural history, and in particular botany, had a leading role. There were also now two fellows of the Royal Society on board, giving the expedition the highest scientific credentials.

John Ellis, the botanist who had been instrumental in inviting Solander to London and who had known Banks since 1764, wrote to Linnaeus telling him about the forthcoming voyage (Carter 1988; Linnean Society, Linnean Correspondence, 19 August 1768). Ellis's main message to Linnaeus was that his student, Daniel Solander, was accompanying Joseph Banks, whom he described as a very wealthy man, to the South Seas. Ellis added that they were very well -equipped, with a fine library and all of the tools necessary to collect and preserve natural history specimens; or, in Ellis's own words- 'No people ever went to Sea better fitted out for the purpose of Natural History, nor more elegantly'. What Ellis did not mention was the huge quantity of cases and book-shelving that Banks was taking on board -'such a Collection...as almost frighten me' Banks remarked (Chambers 2008- 
2014, 16 August 1768). Banks and his suite were given rooms next to Cook's. The 'scientific gentlemen' would be sharing his great cabin, specimens in bottles and in presses, nets and hooks, and sheets of drawing paper jammed up next to maps and mathematical instruments (Chambers 2008-2014, 18 August 1768). Deferentially, Ellis concluded his letter to Linnaeus by saying that 'All this is owing to you and your writings'.

On 30 July 1768, Cook received his instructions. He was to take the ship to Port Royal Harbour by way of Cape Horn. On the way, the Lords of the Admiralty remarked, 'You are at Liberty to touch upon the Coast of Brazil, or at Port Egmont in Falkland Isles, or at both in your way thither'. The first stop though was Madeira, where Cook was ordered to 'take on board such a Quantity of Wine as you can Conveniently stow for the use of the [Ship's] company' (Beaglehole 1955). And so, on 25 August, the Endeavour, with almost one hundred men on board, ten of whom had already been to the Pacific on the two previous voyages of HMS Dolphin, and had already been to Madeira, left Plymouth for the Pacific Ocean.

Now the second tipping point. Considering what Madeira had to offer Cook in the way of vital supplies, its choice as the first destination was reasonable, but it could just as easily have been Tenerife as it was for other naval and merchant ships. Where a ship is concerned, nothing is set in stone: contrary winds, or inclement weather, or sudden shipboard illnesses could easily have made Cook steer for another location for wine supplies -the decision was entirely his. As it turned out, the weather was kind and the crew in excellent shape.

As soon as Banks learned about the stop in Madeira, he would have begun acquainting himself with examples of the island's flora as they were represented in the British Museum's herbarium, essentially the herbarium that had belonged to Sloane and on which Solander was working (Carter 1988).

On 12 August 1768, at about ten in the evening, HMS Endeavour, came to anchor in Funchal's semi-protected harbour as planned, next to HMS Rose, on its way to North America, and several merchant ships. Banks and Solander had already begun collecting and Sydney Parkinson drawing as the ship had slowly made its way southward (Chambers 2008-2014, 1 December 1768). Now, and for the first time, they could extend their practices to include plants.

'This country is very mountainous', Sydney Parkinson noted in his journal, 'yet it is cultivated to the very tops of the mountains; and, being covered with vines, citrons, oranges, and many other fine fruit-trees, it appears like one wide, extended, beautiful, garden (Parkinson 1784).' It was not the best time of the year to collect yet by the end of their five days' stay, over 300 species of plants, many of which were cultivated, had been collected -Solander reported to Linnaeus that of these 50 or 60 were new species (Beaglehole 1962; Duyker and Tingbrand 1995, 1 December 1768). Thomas Cheap, a prominent Madeira wine export merchant and English consul on the island, offered Banks and Solander horses and guides but if these were used, it was not intensive since the radius of collection did not exceed 5 kilometres (Beaglehole 1962). Cheap was generous -he also offered Banks and Solander his house, which they accepted- but it was Thomas Heberden, the resident physician, who proved more useful (Heberden 1990). Heberden, who had been on 
the island for twenty years (he had also spent seven years on Tenerife before that), had a distinct scientific bent and had been elected to the Royal Society in 1761 . Both Banks and Solander would have known about him since he had had several of his scientific papers published in the Royal Society's Philosophical Transactions in the 1750s and 1760s. Solander thought he was a very accomplished naturalist and 'very communicative', and that his Royal Society connections gave him much caché, 'the oracle of the Island', as he referred to him (Duyker and Tingbrand 1995, 1 December 1768). Both Banks and Solander made their appreciation of his help known to their correspondents in London.

Cook was ready to leave. He loaded the ship with water, onions and beef and almost 14,000 litres of the finest Madeira wine. This may sound excessive but once the number of drinkers and the length of time expected at sea and distant from another supply of wine is taken into account, it is not as great as all that. They set sail for Rio de Janeiro on 18 September 1768.

The time to cross the Atlantic (it took almost two months) was used by Banks, Solander and Parkinson (and perhaps also by the other two artists/ naturalists accompanying them, Alexander Buchan and Herman Spöring) to classify and produce colour drawings of some of the specimens (Rose 2018; Duyker and Tingbrand 1995, 1 December 1768). One of these, a plant which Solander referred to as Heberdenia excelsa, in the family Primulaceae, was certainly completed in this manner.

Madeira was significant to the Banksian suite because it was the first time they were able to try out a system which, if successful, they intended to use throughout the expedition: namely to collect, describe and classify, with a Linnaean and, if possible, a local name, to draw and to preserve (a fuller discussion of this aspect of the voyage can be found in Francisco-Ortega et al. 2015a and FranciscoOrtega et al. 2015b). But Madeira was important in another way too.

As John Ellis pointed out in his letter to Linnaeus, Banks had a library with him. Unfortunately, there is no list of the titles, but about seventy of them have been deduced (Carter 1988; Carr 1983). Of course, and it is no surprise, there was a copy of the second edition of Species Plantarum. It is not, however, the presence on board of this book that is significant for our understanding of the history of researches into Madeira's botany, but rather it is the presence of Hans Sloane's Voyage to the Islands, Madera, etc., which requires a moment of reflection.

Sloane was in Madeira for a few days in 1687 on his way to the Caribbean and made a significant collection which he recorded on two occasions, once in 1696 and the other, more significantly, in his two -volume narrative of his travels, published in 1707 (Menezes de Sequeira et al. 2010; Francisco-Ortega et al. 2010; Delbourgo 2017).

Sloane's plant collection (as well as those of others Sloane acquired) was organized according to John Ray's system and it was Solander's task to reclassify it according to the newer Linnaean system (Rose 2018). This Solander began to do soon after early March 1763. To help him produce a catalogue of the first few volumes of Sloane's herbarium, Solander used a clean copy of Sloane's A Voyage, which Joseph Banks provided for him, transferring Sloane's annotations, from his 
own copy that he had bequeathed to the Museum, and adding the Linnaean names mostly from the 1762-3 edition of Species Plantarum.

Sloane's $A$ Voyage, annotated and revised by Solander, was brought to Madeira in September 1768. It must have been a special moment. Solander, Linnaeus's student, holding Banks's copy of a book written by Hans Sloane, the founder of the British Museum, with the first published description of Madeiran plants, now revised for the new botanical age.

Recibido: marzo de 2019; ACEPTAdo: mayo de 2019 


\section{REFERENCES}

Beaglehole, J.C. 1955. The Journals of Captain James Cook on his Voyages of Discovery. Volume 1, Cambridge: Cambridge University Press 684 pp.

Beaglehole, J.C. 1962. The Endeavour Journal of Joseph Banks 1768-1771. Sydney: Angus and Robertson 882 pp.

Beaglehole, J.C. 1974. The Life of Captain James Cook. Stanford California: Stanford University Press 760 pp.

CARr, D.J. 1983. The books that sailed with the Endeavour. Endeavour 7: 194-201.

Carter, H.B. 1988. Sir Joseph Banks 1743-1820. British Museum (Natural History) 671 pp.

Carter, H.B. 1995. The Royal Society and the voyage of HMS Endeavour 1768-1771. Notes and Records of the Royal Society of London 49: 245-260.

Chambers, N. (ed.). 2007. The Scientific Correspondence of Sir Joseph Banks. London: Pickering and Chatto 3088 pp.

Chambers, N. (ed.). 2008-2014. The Indian and Pacific Correspondence of Sir Joseph Banks. London: Pickering and Chatto 608 pp.

Cock, R. 1999. Precursors of Cook: the voyages of the Dolphin, 1764-1768. The Mariner's Mirror 85: 30-52.

Cook, A. 2004. James Cook and the Royal Society. In: Williams, G. (ed). Captain Cook: Explorations and Reassessments, Suffok, UK: Boydell Press, pp. 37-55.

Delbourgo, J. 2017. Collecting the World: The Life and Curiosity of Hans Sloane. UK: Penguin 488 pp.

Duyker, E. 1998. Nature's Argonaut: Daniel Solander 1733-1782. Melbourne: Melbourne University Publishing 338 pp.

Duyker, E. and Tingbrand, P. (eds.). 1995. Daniel Solander: Collected Correspondence 1753-1782. Oslo: Scandinavian University Press 466 pp.

Francisco-Ortega, J., Santos-Guerra, A., Jarvis, C.E., Carine, M.A., Menezes de Sequeira, M. and Maunder, M. 2010. Early British collectors and observers of the Macaronesian flora: from Sloane to Darwin. In: Williams, D. M. and Knapp, S. (eds). Beyond Cladistics: The Branching of a Paradigm. California: University of California Press, pp. 125-144.

Francisco-Ortega, J., Santos-Guerra, A., Romeiras, M.M., Carine, M.A., Sánchez-Pinto, L. and Duarte, M.C. 2015a. The botany of the three voyages of Captain James Cook in Macaronesia: an introduction. Revista de la Academia Canaria de Ciencias 27: 357-410.

Francisco-Ortega, J., Santos-Guerra, A., Sánchez-Pinto, L., Duarte, M.C., Rouhan, G., Santiago-Valentín, E., Carine, M. and Romeiras, M.M. 2015b. Early scientific illustrations of the Macaronesian flora: an introduction to pre- $19^{\text {th }}$ century artworks. Vieraea 43: 219-308.

GLYN, L.B. 2002. Israel Lyons: a short but starry career: the life of an eighteenth-century Jewish botanist and astronomer. Notes and Records of the Royal Society of London 56: 275-305.

Heberden, E. 1990. Thomas Heberden 1703-1769: surgeon, physician and naturalist. Curtis's Botanical Magazine 7: 131-133.

Knight, C. 1933. H.M. Bark Endeavour. Mariner's Mirror 19: 292-302. 
Menezes de Sequeira, M., Santos-Guerra, A., Jarvis, C.E., Oberli, A., Carine, M.A., Maunder, M. and Francisco-Ortega, J. 2010. The Madeiran plants collected by Sir Hans Sloane in 1687, and his descriptions. Taxon 59: 598-612.

Patel, S. (ed.). 2016 Exploration of the South Seas in the Eighteenth Century: Rediscovered Accounts. Routledge 850 pp.

Parkinson, S. 1784. A Journal of a Voyage to the South Seas, In His Majesty's Ship Endeavour. London: Charles Dilley 212 pp.

Rose, E.D. 2018. Specimens, slips and systems: Daniel Solander and the classification of nature at the world's first public museum, 1753-1768. British Journal for the History of Science 51: 205-237.

Salmond, A. 2010. Aphrodite's Island. California: University of California Press 544 pp.

Williams, G. 1996. “To Make Discoveries of Countries Hitherto Unknown”: the Admiralty and Pacific exploration in the eighteenth century. Mariner's Mirror 82: 14-27.

Williams, G. 1998. The Endeavour voyage: a coincidence of motives. In: Lincoln, M. (ed). Science and Exploration in the Pacific. Suffok, UK: Boydell Press pp. 3-18.

Woolf, H. 1959. The Transits of Venus: A Study of Eighteenth-Century Science. Princeton: Princeton University Press 258 pp.

Wulf, A. 2012. Chasing Venus: The Race to Measure the Heavens. London: William Heinemann 336 pp. 